\title{
A NEW LOOK AT THE CURE OF FOLLY
}

\author{
by
}

\section{WILLIAM SCHUPBACH*}

THE MEDICAL and surgical scenes depicted by Netherlandish artists of the sixteenth and seventeenth centuries have attracted the admiring attention of historians of medicine to such a degree that almost no book on "art and medicine" omits such paintings as Jan Steen's $A$ love-sick (or pregnant) girl visited by a physician (several versions) or Gerrit Dou's Quacksalver (Rotterdam, Boymans-van Beuningen museum), although their documentary value is problematical. ${ }^{1}$ Almost as popular are the paintings and graphics which illustrate the scene known in Dutch as Het snijden van den $k e i$, in French as La pierre de tête or La pierre de folie, in English as The cure of folly, and in German as Der Steinschneider. In these scenes, a medical practitionerphysician, surgeon, barber-surgeon or quack, or a combination of those four-makes an incision in the patient's scalp and appears to extract from it a foreign body, usually a stone, the pierre de tête, which, according to contemporary inscriptions, had caused the patient to be afflicted with some kind of mental disorder ("folly").

One of the first modern writers to discuss these scenes, writing about the version in the Prado (Madrid) which is attributed to Hieronymus Bosch, interpreted it as a fantastic suggestion to the surgeons, comparable to Swift's suggestion of reciprocal hind-brain transplants for contentious politicians. ${ }^{2}$ This interpretation was soon overcast by another, which was first put forward by Henry Meige of the Salpêtrière in a fascinating and persuasive series of articles. ${ }^{3}$ The Persian physician Rhazes

*William Schupbach, M.A., Wellcome Institute for the History of Medicine, 183 Euston Road, London NW1 2BP.

1 I thank Renate Burgess for explaining the problems to me, and also for making improving comments on the draft of this paper. On the "love-sick girl": J. B. Bedaux, "Minnekoorts-, zwangerschaps- en doodsverschijnselen op zeventiende-eeuwse schilderijen', Antiek, 1975, 10: 17-42; Tot lering en vermaak, exhibition catalogue, Amsterdam, Rijksmuseum, 1976, nos. 30, 61, 63. On Dou's Quacksalver: E. de Jongh, Zinne- en minnebeelden in de schilderkunst van de zeventiende eeuw, [Amsterdam], Nederlandse Stichting Openbaar Kunstbezit and Openbaar Kunstbezit in Vlaanderen, 1967, pp. 70-75. On the interpretation of "genre" pictures: Hessel Miedema, 'Over het realisme in de Nederlandse schilderkunst van de zeventiende eeuw', Oud-Holland, 1975, 89: 2-18.

2 Carl Justi, 'Hieronymus Bosch', Miscellaneen aus drei Jahrhunderten spanischen Kunstlebens, 2 vols., Berlin, G. Grote, 1908, vol. 2, pp. 61-93, esp. pp. 75-76 (a paper first published in 1889). Jonathan Swift, Gulliver's travels, part III, chapter 6, perhaps inspired by the "Lustucru" series of engravings (see Brabant, op. cit., note 10 below).

3 Henry Meige, 'Les peintres de la médecine (écoles flamande et hollandaise): les opérations sur la tête', Nouvelle Iconographie de la Salpêtrière, 1895, 8: 228-264, 291-322; 'Les arracheurs de "pierres de tête", Janus, 1896, 1: 393-396, 497-502; 'Les peintres de la médecine (écoles flamande et hollandaise): documents nouveaux sur les opérations sur la tête', Nouvelle Iconographie de la Salpêtrière, 1898, 11: 199-212, 320; "Un nouveau tableau représentant les arracheurs de "pierres de tête", ibid., 1899, 12: 170-176; 'Les peintres de la médecine (écoles flamande et hollandaise): "pierres de tête", et "pierres de ventre", ibid., 1900, 13: 77-99; 'L'opération des pierres de tête', Aesculape, 1932, 22: 50-62. Meige's photographic collection of pierre de tête pictures is now in the Wellcome Institute. 


\section{William Schupbach}

(c. 854-925 or 935) denounced certain quacks of his own time who pretended to cure epilepsy by making an incision in the patient's head and appearing to extract from it an object, which in reality they already held in the palm of the hand.4 Unaware of Rhazes' statement, Meige suggested that this "palming" trick was the very scene depicted in the pierre de tête pictures which Bruegel, ${ }^{5}$ Jan Steen and others created more than five hundred years later. There are numerous passages in contemporary Netherlandish literature which express the notion that mental illness was caused by a pathological stone in the head, and it was this belief that the quacks exploited with their false operation. ${ }^{6}$

Meige could have pointed out that this belief was no groundless superstition, for it could have been supported by reliable accounts of post-mortem dissections at which eminent physicians had found calculi in the brains of sufferers from migraine and similar disorders. ${ }^{7}$ The pierre de tête operation thus conceived, although it was fraudulent, need not have been maleficent, for, as Meige found in his own practice, sufferers from migraine or facial neuralgia were only too keen to inflict on themselves any pain which would distract them from the greater pains of their illness-the modern principle of counter-irritation. Such people would have submitted gladly to a pierre de tête operation, as would those who suffered from the delusion that they had a foreign body such as a stone or a wasp inside their skulls. Such delusions are well known to psychiatrists. The quack who pretended to extract a pierre de tête would have used the classic psychiatric strategy of playing along with the patient's delusion, and leading it to the point at which it lost its consistency or its raison d'être. ${ }^{8}$ We know that equally devious tactics were used in similar cases, not only by quacks but also by the most upright physicians, as for instance Nicolaas Tulp in his treatment of the melancholiac delusions of a celebrated painter. ${ }^{9}$

This interpretation of Meige's has been widely circulated and often endorsed in the literatures of both medical and art history. ${ }^{10}$ Yet it raises doubts. The large number

- Rhazes, Liber nonus ad Almansorem, Venice, O. Scotus for B. Locatellus, 1497, tract. 7, cap. 27, fol. 35r. These quacks were no doubt simulating the various operations for mental diseases described e.g. by Al-Zahrāwi in his Surgery, and illustrated in e.g. Österreichische Nationalbibliothek cod. CVP Ser.n. 2641.

'In this paper "Bruegel" or (in citations) "Brueghel" means Pieter Bruegel the elder [c. 1527-1569].

- Meige, op. cit., note 3 above, 1895, pp. 240-241. Woordenboek der nederlandsche taal, 's-Gravenhaage, M. Nijhoff, and Leiden, A. W. Sijthoff, 1926, 7 (1): s.v. kei (1) (D), cols. 2049-2051.

' J. G. Schenck a Grafenberg, Lithogenesia, Frankfort, M. Becker for widow and sons of T. de Bry, 1608, pp. 1-2.

8 Meige, op. cit., note 3 above, 1895, p. 242; op. cit., note 3 above, 1932, p. 54; Celsus, De medicina, III, 18; Paul Richer, $L$ ' art et la médecine, Paris, Gaultier Magnier, [1902], p. 453.

- William S. Heckscher, Rembrandt's anatomy of Dr. Nicolaas Tulp, New York, New York University Press, 1958, pp. 77-78, 179-181.

${ }^{10}$ A sample of implied or express endorsements of Meige's interpretation: René de Bastelaer and Georges Hulin de Loo, Peter Bruegel l'ancien: son oeuvre et son temps, 2 vols., Brussels, G. van Oest, 1905-1907, text vol., pp. 33, 92-94; Louis Maeterlinck, Le genre satyrique dans la peinture flamande, Ghent et al., Librairie néerlandaise et al., 1903 (Mémoires couronnés et autres mémoires, Académie royale de Belgique, 1903, 42), pp. 234, 271-272; idem, Le genre satyrique fantastique et licencieux dans la sculpture flamande et wallonne, Paris, J. Schemit, 1910, p. 135, 137 [this misericord, however, shows not a pierre de tete but a smaller version of the white buns or spheres of stone (?) discussed in the J. Warburg and Courtauld Institutes, 1974, 37: 336-342]; Eugen Holländer, Die Karikatur und Satire in der Medizin, 2nd. ed., Stuttgart, F. Enke, 1921, pp. 198-202; idem, Die Medizin in der klassischen Malerei, 3rd. ed., Stuttgart, F. Enke, 1923, pp. 409-424; J. B. F. van Gils, 


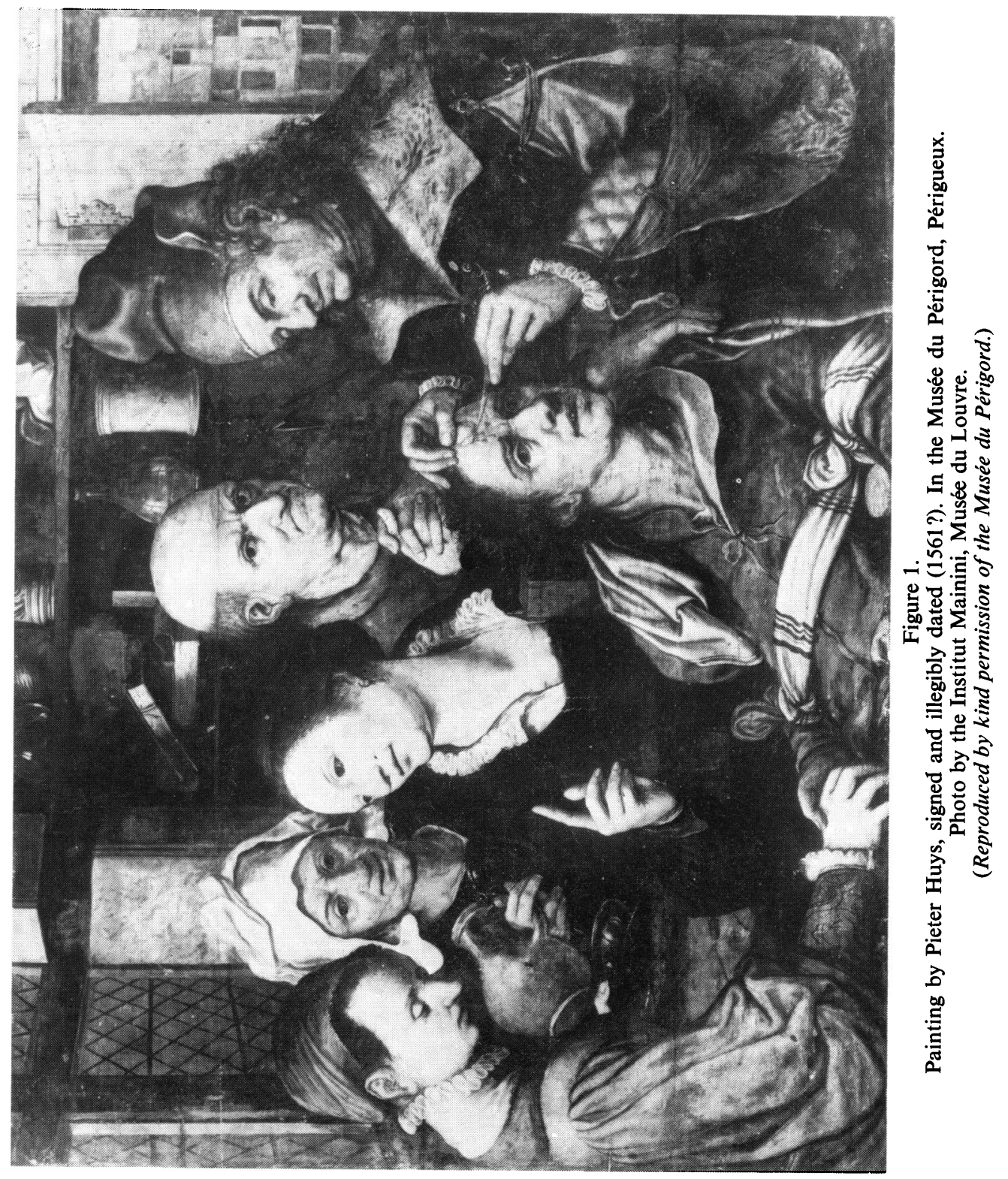



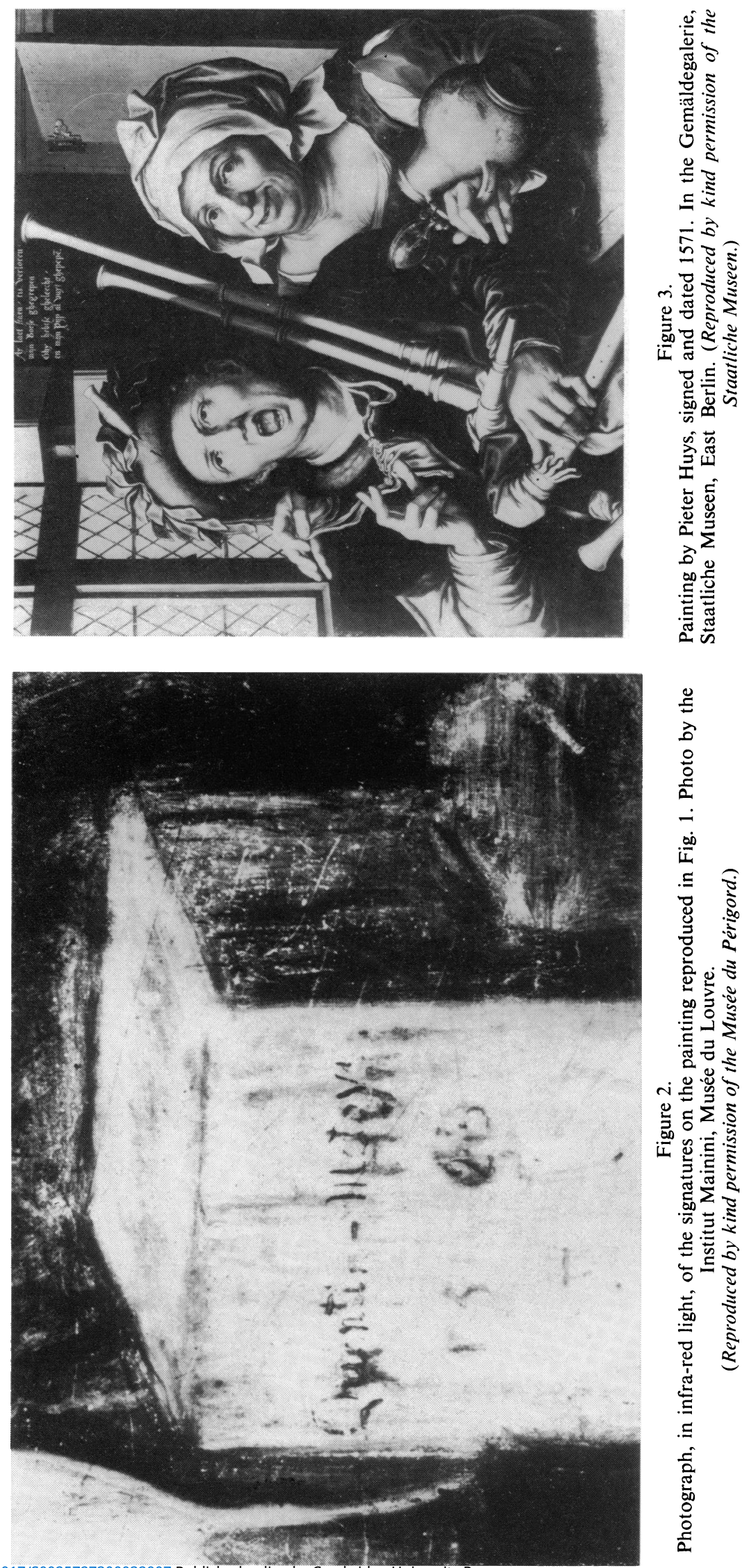


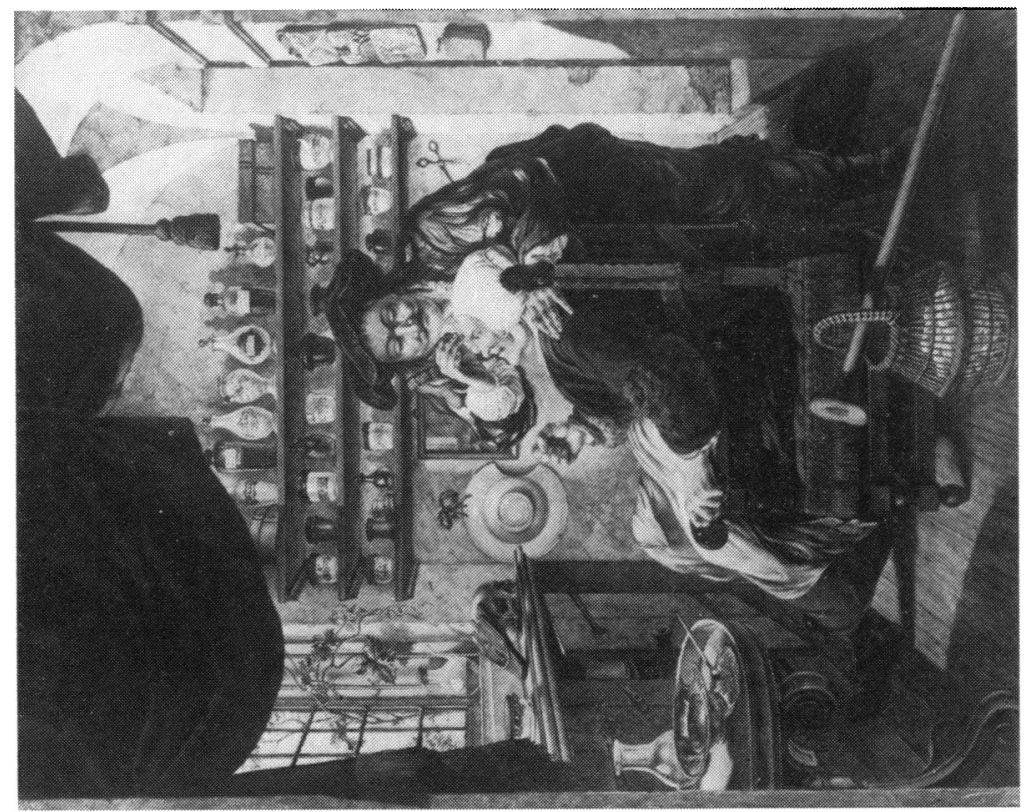

๘ั

क्षे

施

-

ఫ્ّ :

응

ํํㄹ

ฮญ ญ

语的

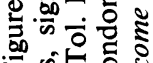

证的政

ขึ

ㅇํㅇ 원돈

跣

긍ํㅇ

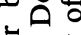

흥조웡

인.

告.

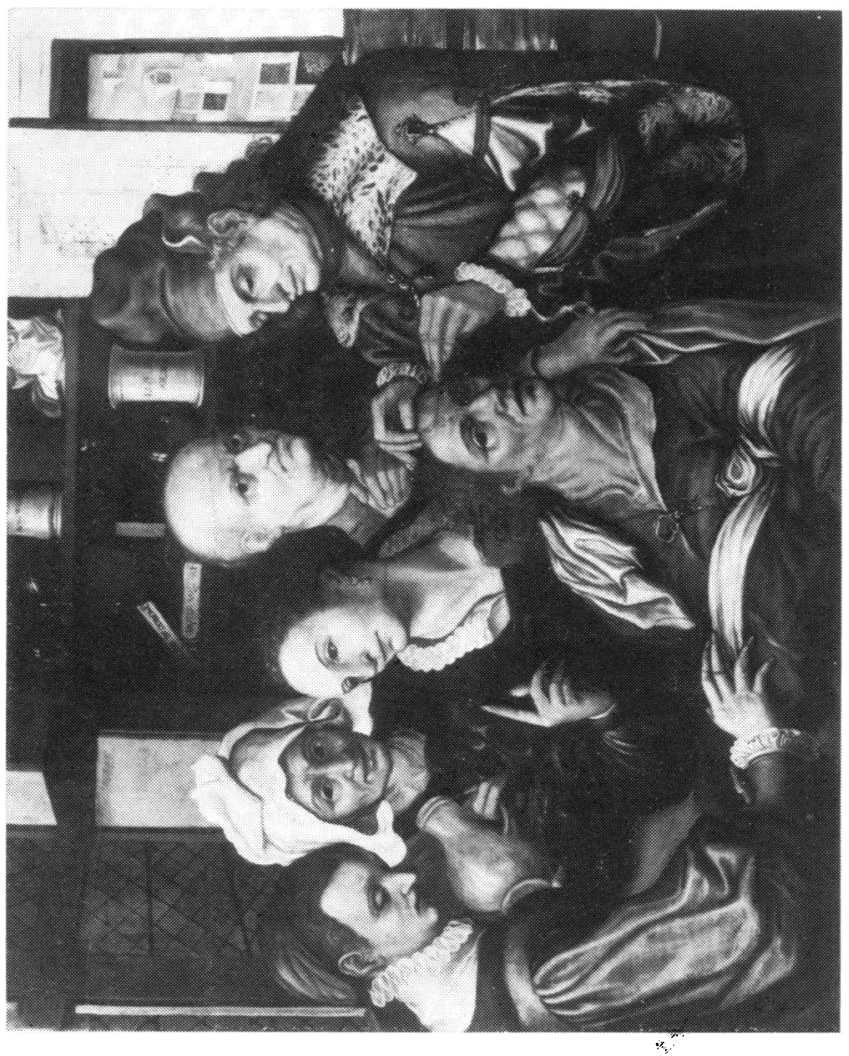

$\stackrel{\text { sे }}{ \pm}$

เั้ ธัง

视

吾

동

초

을

30

3 चे

. ญ

용

$\dot{\square}-\overrightarrow{2}$

.

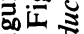

证.

ठू ญे

ํํㅇ

을

D

禹

.를

涪

效

फे

各产 


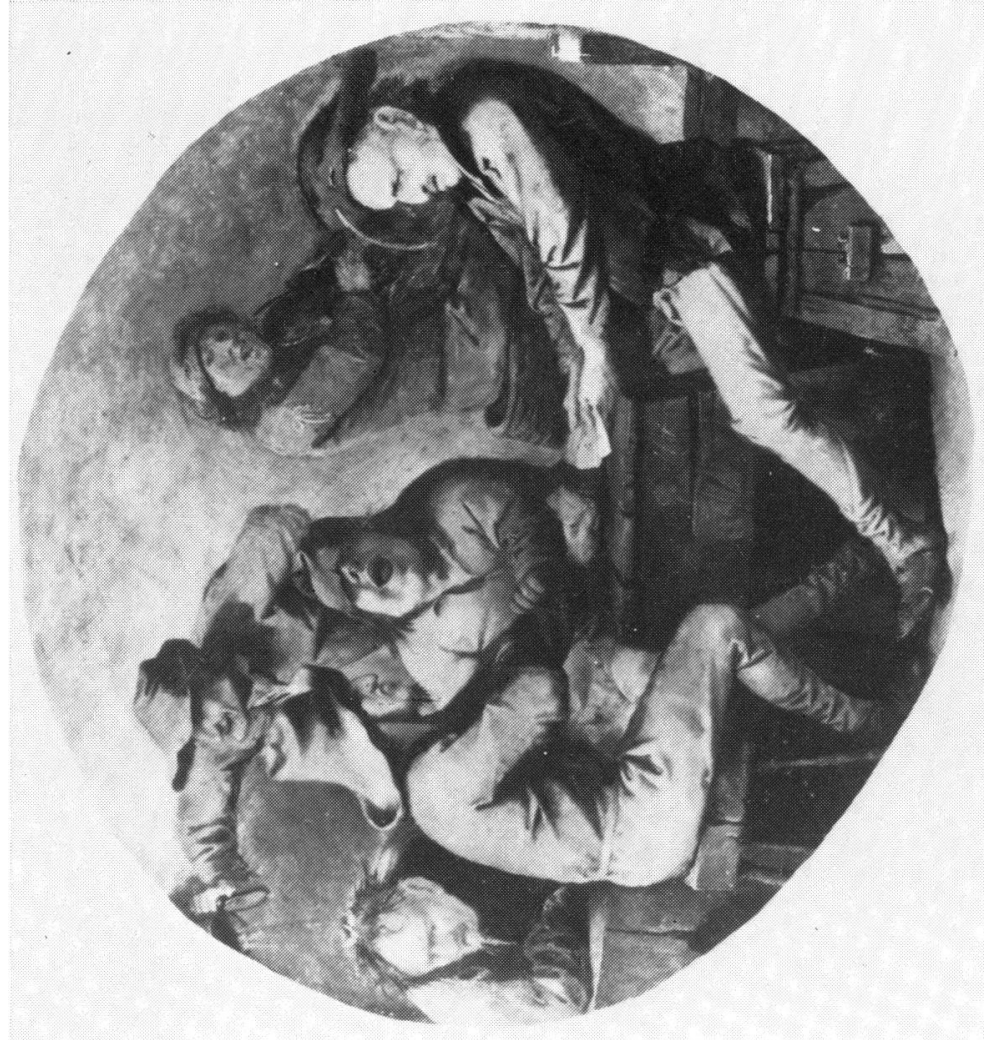

要

हี่

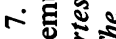

里

䆛 8

记

0 跤

ฐ ฐ

돈호

这

ปี่

鸟

잉

조을

올

疍

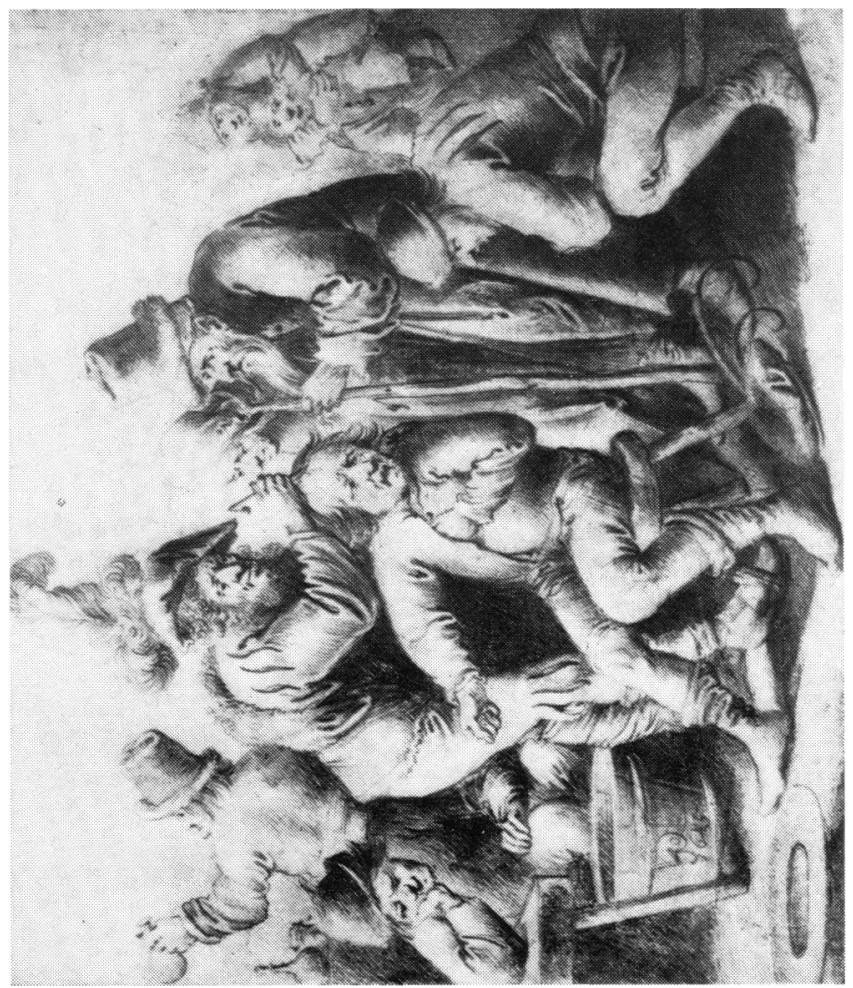

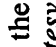

동

ษั่

ช్

홍

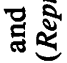

氖

छํํำ

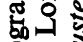

○. 촐

을.ํㅠ

究

证范范

总

包恣

วิ

본

空

ฉ

ธ동

ํㅗㄹ

宓 


\section{A new look at The cure of folly}

of works which depict this subject implies that, in their time and place, the operation was frequently attempted, but no reference to it in documents or non-fictional texts has ever been cited; on the contrary, the pictures have been all the more valued precisely because of the want of such texts. A second doubt: how safe is it to treat works by painters such as Bosch, Bruegel, and Lucas van Leiden as genre-scenes? Admittedly pierre de tête scenes also appear in the works of the later painters Brouwer, Teniers, and Quast, who did paint genre-scenes, but features which now seem to be touches of realism have often turned out to have been originally intended as symbols, as in the paintings of Pieter Aertsen and Jan Steen. ${ }^{11}$

For these reasons, some have denied that the pierre de tête scenes illustrate a real operation, whether performed by quacks or by conscientious practitioners. According to this minority of disbelievers, the pierre de tête paintings simply illustrate the popular phrases "to have a stone in one's head" (to be imbecile), "to have a stone cut out of one's head" (to be cured of imbecility, or, in view of the non-existence of such a stone, to be deceived). ${ }^{12}$ These phrases were enacted as tableaux vivants on

'Het snijden van den kei', Nederlandsch Tijdschrift voor Geneeskunde, 6 April 1940, 84: ii (part 14): 1310-1318 (=Bijdragen tot de Geschiedenis der Geneeskunde, 1940, 20: 57-65), especially the last paragraph; Clements C. Fry, 'The sixteenth century cures for lunacy', Am. J. Psychiat., 1946-1947, 103: 351-352; L. Brand Philip, 'The Peddler by Hieronymus Bosch, a study in detection', Nederlands Kunsthistorisch Jaarboek, 1958, 9: 1-81, p. 47; Ludwig von Baldass, Hieronymus Bosch, London, Thames \& Hudson, 1960, p. 219; Leon Binet and Charles Maillant in Hans Schadewaldt et al., Kunst und Medizin, Cologne, M. DuMont Schauberg, 1907 (French edition 1966), pp. 140-143; editorial, J. Am. med. Ass., 17 April 1967, 200 (3): front cover; Margaret Whinney, Early Flemish painting, London, Faber, 1968, pp. 100-101; Louis Lebeer, Catalogue raisonné des estampes de Bruegel l'ancien, Brussels, Bibliothèque royale Albert Ier, 1969, no. 28, p. 86; Joan F. Menden, 'Operation for stones in the head. An engraving by Nicolaes Weydmans', J. Hist. Med., 1969, 24: 211; Patrik Reuterswärd, Hieronymus Bosch, Stockholm, Almqvist \& Wiksell, 1970 (Figura: Uppsala studies in the history of art, n.s., no. 7), no. 4, p. 259; Geerto Snyder, Instrumentum medici, Ingelheim, Boehringer, 1972, pp. 112, 194; Andor Pigler, Barockthemen, 2nd ed., 3 vols., Budapest, Akadémiai Kiadó, 1974, vol. 2, p. 565; Robert S. Kinsman, 'Folly, melancholy and madness' in The darker vision of the Renaissance edited by R. S. Kinsman, Berkeley etc., University of California Press, 1974, pp. 273-320, p. 291; James M. Grabman." "The witch of Mallegem". Print by Pieter Breughel the elder [c. 1528-69]', J. Hist. Med., 1975, 30: 385; Hyacinthe Brabant, 'Les traitements burlesques de la folie aux xvie et xviie siècles' in Université libre de Bruxelles, Folie et déraison à la Renaissance, Brussels, Éditions de l'Université de Bruxelles, 1976 (Travaux de l'institut pour l'étude de la Renaissance et de l'humanisme), pp. 75-95 and discussion pp. 96-97; R. H. Marijnessen, 'Bosch and Bruegel on human folly', ibid., pp. 41-47 and discussion pp. 48-52; Lyckle de Vries, Jan Steen "de kluchtschilder", D. Litt. thesis, Rijksuniversiteit Groningen, 1977, pp. 92-93, 144-145.

${ }_{11}$ Ardis Grosjean, 'Towards an interpretation of Pieter Aertsen's profane iconography', Konsthistorisk Tidskrift, 1974, 43: 121-143. On Jan Steen, compare his Peddler of spectacles (London, National Gallery) with Grauls, op. cit., note 13 below, pp. 147-152; many other works could be cited.

12 Max J. Friedländer thought the Bosch pierre de tête picture an allegory but the Bruegel (?) a genre scene: cf. Early Netherlandish painting, Leiden, A. W. Sijthoff, 1969, vol. 5, p. 55, and Von Eyck bis Bruegel, Cologne, Phaidon, 1956, p. 146. To my knowledge, the reality of the pierre de tête operation has been doubted only by one art-historian, D. Bax, and one medical historian, Daniel de Moulin. By Bax: Ontcijfering van Jeroen Bosch, 's-Gravenhage, Staatsdrukkerij/Martinus Nijhoff, 1949, pp. 205-208; 'Bezwaren tegen L. Brand Philips interpretatie van Jeroen Bosch' Marskramer, Goochelaar, Keisnijder en voorgrond van Hooiwagenpaneel', Nederlands Kunsthistorisch Jaarboek, 1962, 13: 1-54, p. 22; and 'Jeroen Bosch en de Nederlandse taal', in Jheronimus Bosch: bijdragen bij gelegenheid van de herdenkingstentoolstelling te 's-Hertogenbosch, Eindhoven, Lecturis, [1967?], pp. 61-71. He is followed by anon. [G. Lemmens or E. Taverne], Jheronimus Bosch, exhibition catalogue, 's-Hertogenbosch, Noordbrabants Museum, 1967, no. 30 (Prado version of Bosch pierre de tête scene), but on no. 31 (Rijksmuseum version) the same or the other anonym takes the 


\section{William Schupbach}

procession floats and in farces, as for instance at Antwerp in 1563, when the pierre de tête operator was called "Meester Faes Luerequack", and the scene illustrated his avarice. ${ }^{13}$ The pierre de tête pictures might, on this view, have been made as designs for, or permanent records of, such performances.

But this derivation is well known to those who follow Meige's interpretation. Their point is that the proverb might have given rise to the tableaux and the tableaux to the paintings, or the paintings might have preceded the tableaux, but any of the three could have left some people uncertain whether the pierre de tête really existed or whether it was only a figure of speech: it was that uncertainty that was exploited by the quacks. If the phrase could be used to imply ill-gotten gain, it must have been associated with quackery. But we still do not know whether "Master Luerequack" and such figures were drawn from reality or from fiction.

However, on the question as to whether the operation was or was not performed in reality, there is substantial negative evidence. Several contemporary books describe the activities of quacks in the Netherlands in the sixteenth and seventeenth centuries: none of those cited here mentions the pierre de tête operation. ${ }^{14}$ Other works, written at the same time and place, describe the fraudulent tricks used benevolently by physicians in order to cure delusions: these works also are silent on the pierre de tête operation. ${ }^{15}$ There are documents in the form of edicts and remonstrances which describe the practices of quacks in Dutch and Flemish towns: the operation for pierre de tête is not included. ${ }^{16}$ Yet all three types of literature agree amongst them-

Meige line. Bax is also followed by W. S. Gibson, Hieronymus Bosch, London, Thames \& Hudson 1973, p. 40. By D. de Moulin: 'Grepen uit de oude geneeskunde', in Ziek zijn, vroeger, Heeze Brabantse Dag, 1974, pp. 9-19, p. 14; (with I. M. de Groot) "'The cutting of the stone": an engraving by Johannes Theodoor de Bry', Organorama, 1974, 11 (2): 28-30. The present article was written independently of this article by de Groot and de Moulin, who reach similar conclusions by following parallel arguments through different examples-without citing any evidence, however.

${ }^{18}$ P. de Keyser, 'Rhetoricale Toelichting bij het Hooi en den Hooiwagen', Gentsche Bijdragen tot de Kunstgeschiedenis, 1939-1940, 6: 127-138, p. 135; Jan Grauls, 'Ter Verklaring van Bosch en Bruegel', ibid., pp. 139-160; and other articles by Grauls, Lebeer, and Roggen in the same and the preceding volume.

14 Franciscus Rapardus (Rapaert, physician of Bruges), Magnum et perpetuum almanach . . . ut merito dici posset vulgarium prognosticorum, medicarum, empiricorum medicastrorum flagellum, Antwerp, J. Latius, 1551; Gabriel Ayala (physician residing in Brussels), Popularia epigrammata medica, Antwerp, G. Silvius, 1562, fols. 17r-18v, 'In empyricos et mulomedicos', fol. 37v 'de nephariis pharmacopolis'; Petrus Talpa ("Stellincweruius", a physician), Empiricus sive indoctus medicus, Antwerp, G. Silvius, 1563; Petrus Forestus, De incerto fallaci urinarum judicio. Leiden, Plantin for F. Raphelengius, 1589 (and later editions in various languages); Dionysius Thriverus (physician of Louvain, then of Zierikzee in Zeeland) in his preface dated 1591 to Hieremias Thriverus Brachelius' Universae medicinae brevissima absolutissimaque methodus, Leiden, Plantin for F. Raphelengius, 1592, fols. ${ }^{*} 3 \mathbf{r}-* 7 r$.

${ }_{1 s}$ Gabriel Ayala, op. cit., note 14 above, fols. 16v-17r, 'De honestis medicorum imposturis'; Levin Lemnius, De habitu et constitutione corporis quam . . . complexionem vocant, Erfurt, E. Mechlerus, 1582, pp. 179-180; cf. Heckscher, loc. cit., note 9 above. The same few cases are repeated by many other writers, sometimes accurately.

16 BRUSSELS, 1540 (edict of Charles V): J. G. W. F. Bik, Vijf eeuwen medisch leven in een Hollandse stad, Assen, van Gorcum, [n.d., c. 1955], pp. 496-498; UTRECHT, 1548; A. J. van der Weijde, 'Maatregelen tegen kwakzalvers in 1548', Nederlandsch Tijdschrift voor Geneeskunde, 1923, 67: if, 905 (=Bijdragen tot de Geschiedenis der Geneeskunde, 1923, 3: 220); ANTWERP, 1572 (renewed 1580, 1581, 1643): René Boisson, Chroniques chirurgicales ou histoire des barbiers, chirurgiens, dentistes de Belgique et du Nord de la France, Brussels, édition Dorka, 1970, pp. 366-367; GOUDA, 


\section{A new look at The cure of folly}

selves on what quacks actually did, and the image they offer is the same as that depicted in non-caricatural pictures of quacks excluding pierre de tête operators. The quacks set up stages or stalls in town- and village-squares, and after attracting a crowd by means of a harangue, music, or a comedy, they offered for sale panaceas, purges, tooth-paste etc., extracted teeth, and advertised their skill in cutting for bladder-stones or hernia. Their successes in the bladder-stone operation were proclaimed in the alleged calculi which were strung over their stalls or strapped on to screens. ${ }^{17}$ They displayed testimonials from distinguished clients. They wore on their heads colourful hats, around their necks strings of teeth (sometimes said to have been retrieved from cemeteries), on their fingers arrays of rings. On such minutiae as these the writers and the painters agree, but on the operation for pierre de tête there appears to have been a conspiracy of silence.

The silence of foreign writers is also remarkable, for if the pierre de tête operation were performed at all, it could not have been confined to the Netherlands. Since charlatans travelled all over Europe it is not surprising that the descriptions of quackery left by Netherlandish, French, English, German, Italian, and Spanish writers of the Renaissance are almost ${ }^{18}$ interchangeable, but all alike omit to attribute to Netherlandish quacks the operation for pierre de tête. On the contrary, for the surgeons of Vlissingen (Flushing), where the operation would doubtless have been known were it performed at all, William Clowes, the foremost enemy of foreign quacks in London, had nothing but praise. ${ }^{19}$

Another reason for doubting the reality of this operation is the fact that when Dutch and Flemish artists, including authors of pierre de tête scenes, wished to produce a moralistic picture illustrating the dubious means by which earthly goods could be acquired, they always avoided using the pierre de tête scene. Instead, the medical figures in these moralistic paintings are usually extracting teeth, as in the foreground of the central panel of Bosch's Haywain triptych, and in the anonymous Expulsion of the money-changers by a follower of Bosch and Bruegel (versions in

1615 (remonstrance to the magistrates of the city): Bik, op. cit., this note, pp. 581-582; GOUDA, [n.d.] (rules of surgeons' guild): Bik, ibid., pp. 582-586, esp. p. 584, clause 13; GHENT, 1674: Léon Elaut, 'Het collegium medicum van Gent legt de duim voor kwakzalver Tiercelijn', Pharmaceutisch Tijdschrift voor Belgie, 1955, 32: 1-4 of offprint. Cf. in general M. A. van Andel, Chirurgijns, vrije meesters, beunhazen en kwakzalvers: de chirurgijnsgilden en de practijk der heelkunde (14001800), Amsterdam, van Kampen, 1941 (Patria no. XXIV), pp. 158-176.

17 Erasmus Roterodamus, Ecclesiastes, liber ii, 'de ratione concionandi', in his Opera, 9 vols., Basle, Froben, 1540, vol. 5, p. 738: 'Deforme exemplum est pharmacopolarum qui, mensa in foro posita, ostentant dentes eductos, lapides e vesicis exectos, diplomata magnatum quos a morte revocarint, magnaque vanitate denarrant sua praeclara gesta quaestus gratia.' As a sufferer from stones, Erasmus would naturally have had his attention caught by the sight of these strings. For pictures of them (apart from pierre de tête scenes) see e.g. the woodcut in William Clowes, $A$ brief and necessarie treatise, 3rd ed., London, T. East, 1585, fol. 9v; the painting, attributed to Pieter Goetkint, Demolition of the citadel [of Antwerp], 1577, in the Musée royal des Beaux-Arts, Antwerp; the painting Market scene by Hendrick van Steenwijck the elder, 1598 (Braunschweig, Herzog Anton Ulrich-Museum); and the Kermis by Pieter de Bloot, 1653, in the Bredius Museum, the Hague (no. 141).

${ }^{18}$ The uomini della casa di $S$. Paolo are rarely recorded outside Italy and Malta. On them see Aby Warburg, 'Kulturgeschichtliche Beiträge zum Quattrocento in Florenz', 1929, in his Gesammelte Schriften, 2 vols., Leipzig, Teubner, 1932, vol. 1, pp. 303, 439-440, and plates.

10 William Clowes, $A$ profitable and necessarie booke of observations, London, E. Bollifant for T. Dawson, 1596, p. 7. 


\section{William Schupbach}

Copenhagen and Glasgow museums). Sometimes they appear in the role of a uroscopist, as in Roemer Visscher's emblem book and in paintings illustrating Flemish proverbs. ${ }^{20}$ The pierre de tête scene cannot have carried any weight as an illustration of real deceit.

There is therefore an argumentum ex silentio against the assumption that the pierre de tête operation was performed in reality. Some new evidence to the same effect may be found in two unpublished representations of the supposed operation. The first is a sixteenth-century Flemish painting in the Musée du Périgord at Périgueux, in the Dordogne (see figure 1). ${ }^{21}$ On the right of this picture is a physician or surgeon, wearing a red bonnet and a green cloak bordered with fur. He is making a bloody incision in the forehead of his patient, who is bound loosely into a chair by a white cloth with coloured stripes. Behind the patient and to his right are four observers or assistants: a bald man who clasps his hands in prayer; a young woman comforting the patient with her left hand and calling for silence or attention with her right; an older woman wearing a white bonnet and holding a ewer with an open lid; and at the left of the picture, a girl who holds a bleeding-bowl to catch either blood or the stone which is still beneath the scalp.

The painting at Périgueux is signed on the left vertical back-strut of the chair "Quentin Metsys 15 26", but the signature is a forgery, for on stylistic grounds the painting cannot have been produced by Quentin Matsys (Metsys, etc.). At the Musée du Périgord the painting is currently assigned to Jan Sanders van Hemessen ( $c$. 1500-after 1565). It is true that there are similarities between the painting under discussion and paintings attributed uncontroversially to Hemessen, especially his pierre de tête painting in Madrid (Prado), but there are also great differences. The characters here lack Hemessen's panache, and the execution his virtuosity. An accomplished master such as Quentin Matsys or Hemessen would not have placed the praying man in such a way that there was no room for his left shoulder. The painting at Périgueux is therefore the work of an unidentified minor master, an eclectic imitator working at Antwerp, the home of both the Matsys family and of Hemessen before about 1550, in the second or third quarter of the sixteenth century.

However, the painter of the Périgueux picture can be identified precisely, for an infra-red photograph of the false "Quentin Metsys" signature shows that it was written over another signature of a less marketable artist, who had already signed the painting as follows:

\section{pe[eter] HVIIs \\ 1561 \\ F[ECIT}

(see figure 2: illegible letters for which spaces are available in the painting have been

${ }^{20}$ Roemer Visscher, Sinnepoppen, Amsterdam, Willem Iansz., 1614, book iii, no. 6. Proverbs: Louis Lebeer, 'De Blauwe Huyck', Gentsche Bijdragen tot de Kunstgeschiedenis, 1939-1940, 6: 139-160; Jan Grauls, 'Het Spreekwoordenschilderij van Sebastiaan Vrancx', Bulletin des Musées royaux des Beaux-Arts de Belgique, 1960, 9: 107-164.

21 I am indebted to the initiative and courtesy of M. Soubeyran, Conservator of the Musce du Périgord, Périgueux, for knowledge of the painting in his care, and also for infra-red photographs of it. The dimensions of the painting are $1.09 \mathrm{~m} \times 1.39 \mathrm{~m}$. It is painted on a panel consisting of about four horizontal planks. 


\section{A new look at The cure of folly}

supplied in square brackets). This is the signature of Pieter Huys (1519?-1584?), who became a master of the Antwerp guild of painters in 1545, and who signed his paintings in this way, with minor variations from work to work. ${ }^{22}$ The forger has economically retained the 1 and 5 of the date, but has tampered with the last two digits in order to bring the painting within Q. Matsys' lifetime, which ended in 1530. As a result, the reading of the date as 1561 is not certain; the third digit also looks like a 4, and the fourth like an 8.

It is clear from a comparison with his other works that this pierre de tête picture by Huys cannot be a realistic genre-scene, despite the many touches of genre in the décor and costumes. Leaving aside his four signed demoniacal paintings in the style of Bosch, ${ }^{23}$ the other, unsigned, demoniacal works which are attributed to him, ${ }^{24}$ and the ensign The golden compasses painted to hang over the door of Plantin's printinghouse at Antwerp, ${ }^{25}$ we are left with two relevant paintings: the Piper and woman (East Berlin, Staatliche Museen, Gemäldegalerie no. 693), which is signed and dated $1571,{ }^{26}$ and the unsigned Jester (U.S.A., private collection). ${ }^{27}$ Since the attribution of the Jester has not been substantiated, the argument rests on the Piper and woman (see figure 3). The latter is closely connected with the pierre de tête picture, for the two signatures are similar and the women holding ewers are coloured alike in each painting.

Huys's Piper reveals the same artistic stratagem as his pierre de tête picture: he has taken a composition by van Hemessen (versions in Brussels and Detroit) and reworked it in the manner of the Matsys family. The inscription in the background of

22 The evidence of Huys's life is given by Max J. Friedländer in Ulrich Thieme and Felix Becker, Allgemeines Lexicon der bildenden Künstler, 37 vols., Leipzig, E. A. Seeman, 1907-1950, vol. 18, p. 202. For more recent attributions of paintings: Leo van Puyvelde, La peinture flamande au siecle de Bosch et Brueghel, Paris, Elsevier, 1962, pp. 72-75. See also notes 23, 24, 27, and 30 below. For Huys's signatures see Alfred von Wurzbach, Niederländisches Künstler-Lexicon, 3 vols., Vienna and Leipzig, Halm \& Goldmann, 1906-1911, vol. 1, p. 739. Von Wurzbach omits the signature to the Prado Battle of angels and demons, and torments of hell which is in two lines in the form: " 1570 ! peeter huijs fe.". On engravings by P. Huys see F. W. H. Hollstein, Dutch and Flemish etchings, engravings and woodcuts, Amsterdam. Menno Hertzberger, [n.d.], vol. 9, pp. 169-172.

${ }^{23}$ The three in Paris, Antwerp, and Madrid listed by Friedländer, op. cit., note 22 above, and a fourth brought to my attention by Renate Burgess: a St. Christopher in the Sammlung Oskar Reinhart, at Winterthur. Huys's signature was recently revealed after cleaning. The painting is reproduced in Friedländer, op. cit., note 12 above, 1969, no. 96, pl. 84, as by Bosch or anonymous follower.

${ }^{24}$ van Puyvelde, loc. cit., note 22 above. Art dealers tend to attribute to Huys any unsigned and undocumented painting in the style of Bosch. A recent example: The tribulations of the wise men, Brussels art-trade (Miodrag Boskovitch, 1972; cf. The Burlington Magazine 1972, April, 114: xciii or May, 114: xxxix). See also the list in Bax, Ontcijfering (op. cit., note 12 above), p. 324. Bax, ibid., fig. 131 shows the Grotesque duel on ice on which Friedländer remarked "Bosch'sche Erfindung und Bruegel'sche Ausführung", without endorsing the dealer's nonchalant attribution to Huys (P. de Boer, Cat. von oude schilderijen en teekeningen, [n.d., c. 1935] no. 48).

${ }^{25}$ Leon Voet, The golden compasses, 2 vols., Amsterdam, Vangendt, 1969-1972, vol. 1, pp. 47, 62. Huys also engraved for Plantin: his copper-blocks engraved for Plantin's Valverde edition of 1566 are preserved in the Plantin-Moretus museum at Antwerp (see Voet, vol. 2, plates 33, 43).

${ }^{36}$ Hans Posse, Die Gemäldegalerie des Kaiser-Friedrich Museums, 2 vols., Berlin, Julius Bard, 1911, vol. 2, no. 693, pp. 136-137. The unsigned Piper and woman paintings in Brussels and Detroit which are attributed to Huys are not copies of the Berlin painting, as some have stated. On them and on another version in Düsseldorf see van Puyvelde, op. cit., note 22 above, p. 74.

${ }^{27}$ Published as a work of P. Huys by E. Tietze-Conrat, Dwarfs and jesters in art, London, Phaidon, 1957, front. and p. 85. 


\section{William Schupbach}

the piper painting is spoken by the piper, who protests "Let me be! It is wasted effort to seize my purse: you have emptied it already, and my pipe can play no more."28 This double-entendre places the painting among the allegorical "contrast" pictures. These works show equivocal scenes which contrast traditional pairs such as youth and age, love and money, gullibility and cunning, for example by showing an elderly man being seduced by a young woman, ostensibly for love but really in order to steal his money. The attempted seduction, sometimes depicted realistically, is here shown allegorically, the pipes and the ewer being male and female symbols respectively. ${ }^{20}$ Were it not for the inscription, the painting might be interpreted by some as a genrescene; indeed its official title, Der Dudelsackpfeiffer, suggests that it is a genre-scene.

The pierre de tête painting by Huys is of the same kind. In the original state of the painting, the genre-like surgical scene was set off by inscriptions which revealed its humorous, allegorical, status. Only one now survives in the Périgueux version: others may have been obliterated by the forger of the Matsys signature. Hence the value of a weaker, but close and contemporary copy, in which they have been preserved: the copy is in the Wellcome Institute for the History of Medicine, London. ${ }^{30}$ The inscriptions (see figure 4) attribute to the operator the very disorders of which he is supposed to be curing the patient. The left-hand drug-jar is inscribed CONSARVA VAN WESPEN ("conserve of wasps"), and the left-hand book is marked with the burlesque name of a medical authority, LECTOR BRODRONKEN ("Lector Lustful"). While "to have a stone in the head" implied folly, "to have a wasp (or gadfly) in the head" implied lust. ${ }^{31}$ This interpretation explains the presence of the bonneted woman with the open ewer, whose function in the Piper picture has already been noted. The drug-jar on the right is marked MVELEN POEDER ("mules powder"), and the book on the right DOTER MALLART ("Dr. Fool"). The drugs and medical authorities which the operator is using are thus proclaimed to do nothing but increase the lust and folly of the patient. Since those are the disorders which the

28 van Puyvelde, op. cit., note 22 above, p. 74.

20 A. P. de Mirimonde, 'Le symbolisme musical chez Jérôme Bosch', Gazette des Beaux-Arts, 1971, 77: 19-50, pp. 23-24; Bax, Ontcijfering, (op. cit., note 12 above), pp. 224, 229; Grosjean, op. cit., note 11 above, p. 128. Pieter Aertsen was a master of this kind of visual pun: for example see his Peasant scene in the Mayer van den Bergh Museum, Antwerp.

${ }^{30}$ No. 2745/1939, panel of 4 or 5 planks. The same copyist, presumably a studio pupil, can be seen at work in a painting sold at Sotheby's, London, on 25 June 1969, lot 58 as by Jan van Hemessen. This painting is a weaker copy of a picture, here attributed to P. Huys, which is recorded as in the possession of the Marquess of Lothian (photo in the Rijksbureau voor Kunsthistorische Documentatie, the Hague, from the National Gallery of Scotland). The Huys picture in turn is a variant of Hemessen's Summoning of Matthew in Munich, Alte Pinakothek (no. 11): Huys has omitted the figure of Christ and so produced a Tax-collectors scene similar in composition to the pierre de tête picture. The sizes of the paintings tell their own story:
(a) Hemessen, Summoning of Matthew (Munich) original composition
(b) Huys, 'Tax collectors' (Lothian)
variant of (a)
(c) studio of Huys, 'Tax collectors' (Sotheby)
copy of (b)
$1.15 \times 1.55 \mathrm{~m}$.
(d) Hemessen, Cure of folly (Prado)
original composition
$1.09 \times 1.34 \mathrm{~m}$.
(e) Huys, Cure of folly (Périgueux)
variant of (a) $+(d)+$ others
copy of (e)
$1.08 \times 1.32 \mathrm{~m}$
$1.00 \times 1.41 \mathrm{~m}$.
(f) studio of Huys, Cure of folly (Wellcome)
$1.09 \times 1.39 \mathrm{~m}$

It seems to have originated as a fantastic interpretation of the medical term for lust, oestrus or oestrum, literally a gad-fly. Ayala, op. cit., note 14 above, fol. $4 r$, lists it with epilepsy among the disorders caused by "catarrh". Therefore the "aestrum" in the engraving by de Bry discussed by de Groot and de Moulin, op. cit., note 12 above, means lust, not folly. 
operation was supposed to cure, a contrast is drawn between the operator's pretensions and his actual ability.

But the composition was set up, the characters gathered together from different paintings by other artists, solely in order to make this point. Thus this work joins the allegorical "contrast" scenes, and has as little to do with surgery as the Piper and woman has to do with music. The Jester, the authorship of which is uncertain, is also an allegorical painting, for the jester or fool who looks through his spread fingers illustrates a Flemish proverb. ${ }^{32}$

The subject of the pierre de tête painting by Huys is therefore an allegorical, satirical, burlesque scene put together from paintings by Hemessen (the patient, the praying man, the women with the ewer) and perhaps the family Matsys (the two younger women). ${ }^{33}$ The source of the figure of the operator has not been identified. The profile and the angle of the head remind one of $Q$. Matsys' portrait of Erasmus, but it is probably too subtle to deduce an iconographical relationship between the author of The praise of folly and this picture of The cure of folly. While the hat and costume are plausible as the dress of a surgeon, the jewel on his shoulder appears also on the hat of a banker in a painting in the Royal collection at Hampton Court. Furthermore, the same jewel appears in versions of the Hampton Court painting published from collections in France, Germany, and England, and these versions also show the same curly-handled scissors as appear in Huys' pierre de tête picture and its Wellcome copy. Since the authorship of the Bankers paintings is disputed, one is tempted to propose Huys as the painter of at least one of the versions. ${ }^{34}$ At all events, the presence of these motifs in the Bankers pictures shows that even the figure of the operator cannot be taken as a faithful likeness of a real surgeon.

The second unpublished representation of a pierre de tête scene is a pencil drawing on parchment by Pieter Quast of Amsterdam (1616?-1647): the drawing, which measures $252 \times 295 \mathrm{~mm}$, is in the Wellcome Institute in London (see figure 6). ${ }^{35}$ In the centre of this lively sketch the patient is seated on a three-legged stool. His plumed hat lies on the ground beside him. With his tense right hand he seems to clench a slash in the breeches of the operator, whose hat is more richly plumed than

32 Tietze-Conrat, op. cit., note 27 above, p. 85.

23 The woman with the ewer is also seen in a painting said to be in the Kunsthistorisches Museum, Vienna, but apparently excluded from the catalogue. It was published, with an attribution to van Hemessen, by Ludwig Baldass, 'Sittenbild und Stilleben im Rahmen des niederländischen Romanismus', Jahrbuch der kunsthistorischen Sammlungen in Wien, 1923-1925, 36: 15-46, p. 20.

3 C. H. Collins Baker, Catalogue of the principal pictures in the Royal collection at Windsor castle, London, Constable, 1937, p. 234 and pl. 77; Georges Marlier, Erasme et la peinture flamande de son temps, Damme, Éditions du Musée van Maerlant, 1954, pp. 266-277; Leo van Puyvelde, 'Un portrait de Marchand par Quentin Metsys et les Percepteurs d' Impôts par Marinus van Reymerswale', Revue Belge d'Archéologie et d'Histoire de l'Art, 1957, 26: 3-23. Illustrations of the versions: Lionel Cust, 'Notes on pictures in the Royal collections-XXIII', Burlington Magazine, 1911-1912, 20: 252-258, pl. II. W. MacLean Homan and William Gibson, 'The paintings of two money changers attributed to Quentin Matsys, Marinus van Reymersvaele and others with special reference to the picture in the Royal Collection at Windsor', Witt library, unpublished typescript, [n.d.].

${ }^{25}$ Other pierre de tête pictures by Quast are known, e.g. no. 348 in the Musée des Beaux-Arts, Nimes; no. 212 in the Gemäldegalerie, Bamberg; and, most like the Wellcome drawing, a picture recorded in the archives of the Polska Akademia, Warsaw (photo in the Rijksbureau voor Kunsthistorische Documentatie, The Hague). For Quast's biography see Dieuwke de Hoop Scheffer, 'Een serie bedelaars door Pieter Quast: 't is al verwart-gaeren', Bulletin van het Rijksmuseum, 1974, 22: 166-172, 190-191. 


\section{William Schupbach}

the patient's. Three observers stand around. One of them wears a jacket slashed in the same manner as the operator's. The two others show their anxiety about the imminent operation. To the right, we see a frequent feature of pierre de tête pictures, a man carrying to the operator a patient with a bandaged head. To the left, a man is looking down over a tub. Behind him, another man with his back to us is holding up a flask, the traditional gesture of the uroscopist. On the table before him stand another flask and a drug-jar. On the side of the tub is Quast's PQ monogram and the date 1645. In the left foreground lies a barber's bleeding-bowl. Obviously, many of the details of the picture are realistic, but the picture taken as a whole is not a clear-cut document of medical history.

Some quacks of the sixteenth and seventeenth centuries were so closely involved with theatrical companies that it would be more accurate to regard them as actors who included quackery in their stage routine. During the performance of a comedy or musical show, an actor came on who played the role of a quack. He still acted within the play, and pressed his wares on his fellow actors, who took the roles of the gullible customer and the censorious doctor. Gradually the comedy turned into reality as the actor playing a quack turned his attention from the actors to the audience, while his colleagues on the stage were transformed from his patients into his assistants. ${ }^{36}$

Many pictures which appear to show quacks treating members of the public really show the previous phase, in which the actors played the roles of both quack and patient. $^{37}$ Even theatrical companies which did not have medical quackery as their end, as for instance the Rederijkers, who at Antwerp performed at public expense, ${ }^{38}$ were exploited by quacks, and represented quackery on their stages. For example a painting by Jan Steen shows a quack selling goods to an audience from a stage which has just been vacated by Rederijkers, while the latter are seen at lunch through an upper window of a house emblazoned with the emblem of their company. The quack is making use of the audience which the Rederijkers had gathered for themselves, and he is perhaps keeping its attention until they return for the next act. ${ }^{39}$ But the itinerant troupes of actors who did not have official support often used their comedies and music more as a means of attracting a crowd for the quack than as ends in themselves. The company seen by Thomas Platter in 1598 did not demand payment for their musical comedy, for that merely served to warm up the audience for the quack's salesmanship, which provided ample income for all the actors. ${ }^{40}$

36 Thomas Platter junior, Beschreibung der Reisen durch Frankreich, Spanien, England und die Niederlande 1595-1600 edited by Rut Keiser, 2 vols., Basle, Schwabe, 1968, vol. 1, pp. 305-308, 27 October-24 December 1598; J. W. Muller, 'Robijn en consorten', Tijdschrift voor nederlandsche Taal- en Letterkunde, 1910, 29: 103-121; Andrea Corsini, Medici ciarlatani e ciarlatani medici, Bologna, N. Zanichelli, [1922], pp. 59-60. The successive phases described here may also be seen in the draft (Düsseldorf, Kunstmuseum) and the finished version of Jacques Callot's etching La fiera dell' Impruneta (1620), as Gerald Kahan may have indicated in his Jacques Callot: artist of the theatre, Athens, Ga., University of Georgia Press, 1977 (not seen).

${ }^{37}$ On this and what follows: Albert Heppner, 'The popular theatre of the Rederijkers in the work of Jan Steen and his contemporaries', J. Warburg and Courtauld Institutes, 1939-1940, 3: 22-48.

${ }^{28}$ Prudens van Duyse, De Rederijkkamers in Nederland, 2 vols., Ghent, A. Siffer, 1900-1902, vol. 1, p. 259n.

${ }^{20}$ Heppner, op. cit., note 37 above, p. 32 and pl. 3a.

${ }^{40}$ Platter, loc. cit., note 36 above. 


\section{A new look at The cure of folly}

When a picture shows quacks and their patients throwing exaggerated gestures in farcical situations, there is reason to believe that the scene is inspired by a theatrical event, not a surgical operation. Quast is known to have depicted theatrical scenes, for example the Hooft tableau performed by the Amsterdam Rederijkers (Toneelmuseum, Amsterdam). In the Wellcome drawing the patient's ludicrous gesture and the bystanders' posed expressions are obvious signs of theatrical influence.

The farcical mood can only be appreciated if we understand the roles of the figures on the left, which are comparable to figures in two other pictures by Quast, one of which is illustrated in fig. 7. This illustrates a farcical boor-scene (boerenklucht). The boors are playing cards. On the left we see another man looking down and away from the action, but here he is being douched with a jug of water by the man behind him. In another painting by Quast, formerly in Vienna, the two left-hand figures are also behaving in the same way:11 a stock item of slap-stick comedy. One may therefore deduce that, in the Wellcome drawing, the man who is raising the supposed urineflask rather too quickly up to the light is about to tilt its contents over his shoulder and on to the unwitting day-dreamer, and perhaps on to the operator as well. One can see the uroscopist's sleeve falling into folds as he flexes his left arm and takes aim out of the corner of his eye. This is therefore a comedy performed by actors, not an operation performed by a quack on a sick person. When the farce ends, the operator may turn his attention to the audience, but he will not repeat the pierre de tête operation on them; perhaps the bloodletting bowl will come into use.

Of the two pierre de tête pictures discussed here, then - a Flemish scene of the mid-sixteenth century and a Dutch scene of the mid-seventeenth - neither will bear a documentary interpretation. They thus confirm the evidence that the operation was not performed in reality. Yet the value of these pictures for medical history is still considerable. The unreality of the operation was an incentive to painters like Hemessen to depict an operator, his stall, the patient, the bystanders, and the atmosphere as realistically as possible. In these matters they confirm the literary evidence, but surpass it in vividness and precision. For example, the surgical instrument used by the operator sometimes has a stone suspended from its handle by a string. The stone attached to the ornate lancet used by Huys' bejewelled surgeon is mounted in a gleaming collet. Others, for example those used by Lucas van Leiden's pierre de tête operator (engraving, 1524) or Pieter Quast's in his Wellcome drawing (fig. 6) are more humbly decorated with the same device. This cannot be a fictional decoration for pierre de tête extractors, for it appears in a chiropody scene by Quast.42 The stone on the pierre de tête lancet must be another example of the display of bladder-stones as an advertisement. It does not appear on the lancet of the operator in Hemessen's painting, for there the half-dozen bladder-stones dangling from the stall are conspicuous enough. The stone on the lancet may imply that this was the instrument used by the operator in cutting for bladder-stone. If so, it is no wonder that many victims of that operation died of blood-loss. Pare recommended that in order to

${ }^{41}$ Photo in the Rijksbureau voor Kunsthistorische Documentatie, The Hague, with legend 'Vlg. Dr. H. P., Weenen 5-4-1910'. 46 x 50cm., monogrammed.

is Engraving: S. Savery after P. Quast, [n.d.]. Reproduced by G. van Rijnberk, 'De geneesheer en de geneeskunst in nederlandsche prentverbeeldingen', Bijdragen tot de Geschiedenis der Geneeskunde, 1921, 1: 32-47, fig. 7. 


\section{William Schupbach}

minimize the incision the operator should use a narrow little knife, not a long and heavy lancet like these in the pierre de tête paintings. ${ }^{43}$

It is ironic that artists were enticed into producing these valuable historical documents only by the prospect of including in them a fake item (the operation itself), but it was the very non-existence of the operation which gave point to the picture, a reason for painting it at all. The unreality of the operation, combined with the most plausible realism in the rendering of the circumstantial details, made for a ludicrous effect which art-collectors of the sixteenth and seventeenth centuries must have found irresistible. But although, as we have seen, the superficial realism of these pictures has been even more convincing than their authors ever intended, undue influence has been allowed to one late, exceptional painting which is overtly farcical: Jan Steen's pierre de tête picture in Rotterdam (Boymans-van Beuningen museum). This painting shows a fraudulent operator "palming" a quantity of stones which an accomplice is handing to him one by one. Of the nine characters present, only the patient is unaware of the fraud. This must be one of the farcical scenes inspired by the antics of actor-charlatans whom Steen, as already noted, was always pleased to depict. This is the only pierre de tête painting to show the deceitful sleight of hand mentioned by Rhazes. In the earlier works, it is the painter, not the operator, who has "planted" the stone in its anatomically impossible bed of flesh. The operator, who is of course the painter's creature, performs in all sincerity the absurd operation allotted to him.4 In Quentin Matsys' Allegory of folly (New York, Julius S. Held collection), the figure of folly has a pierre de tête bursting from his forehead, yet there is no hint that anyone but the artist himself has put it there: it is depicted as if it were a genuine pathological tumour. There is therefore no need to suppose that Bosch's or Hemessen's pierre de tête operator is deceitful, or that non-fraudulent operators cannot be extracting pierres de tête. The gravity of such scenes as Lucas van Leiden's engraving (B. 156) far from disqualifying them from the pierre de tête canon, is an almost essential ingredient of it. The impossible operation for pierre de tête was depicted in the same atmosphere as the real operations for the extraction of teeth or the removal of bladderstones. If the operator is shown as a "quack", it is because the latter operations were performed by itinerants, not because the fictitious operation was deceitful. If it were deceitful, one of the main points would be lost, the point that the operator was as foolish as the patient, if not more so, in thinking that folly could be cured as easily as bladder-stones could be removed, difficult though that operation was.

What, then, do the pierre de tête pictures really mean? They seem to be divisible into three overlapping groups. The first group represents a Flemish saying, not a proverb but an idiomatic metaphor. Some compositions (e.g. Bosch's) may be influenced by the tableaux of the Rederijkers, but others (e.g. Huys') are derived from painterly traditions alone. Bosch played on the contrast between the metaphorical saying and its literal depiction, while others brought out the contrasts implicit in the

\footnotetext{
4s Ambroise Paré, Dix liures de la chirurgie, Paris, Jean le Royer, 1564, book 9, ch. 12, fols. 172v173r; cf. ibid., book 7, ch. 9, fols. 104v-105r.

4 This is especially true of Hemessen's pierre de tête picture in the Prado and, mutatis mutandis, of Godfried Schalcken's Uroscopist in the Mauritshuis. Note also that in the Antwerp procession of 1563 it was not the pierre de tête float (no. 6) that represented Deception, but a separate float (no. 3). See note 13 above for text.
} 


\section{A new look at The cure of folly}

saying itself; the ineptitude of attempting a physical cure of a moral disorder (Hemessen, in whose painting bladder-stones hang portentously over the patient's pierre de tête) $;^{.45}$ the contrast between the gravity of the operation and its non-existence (Lucas van Leiden; the genre-inclined followers of Bosch); and the contrast between the operator's folly and his pretensions to cure others of the same vice (P. Huys, probably interpreting Bosch; painting in Rotterdam attributed to Jan de Bray). After a long life, this vein was exhausted in the third quarter of the sixteenth century.

The pierre de tête pictures of the second group show theatrical versions of the scene depicted in the first group. For this purpose it was necessary to introduce the "palming" trick, which had been superfluous as long as the scene was purely fictional. The authors of these scenes, Quast and Steen, were closely attached to theatrical companies: naturally therefore, they depicted the scene as the stage-manager envisaged it, and suppressed the fact that it was only a performance. They introduced low-life elements to make it look like a genre-scene, but the unnaturally high spirits of the characters betray them.

In the third group, the old pierre de tête scene was combined with the newly flourishing medical genre-scene. The results of this combination are often indistinguishable from pure genre-scenes which show the lancing of carbuncles or the removal of sebaceous cysts. Indeed the pierre de tête scene attributed to Teniers was so acceptable as a genre-picture that, like the medical genre-pieces attributed to Rembrandt (Bredius-Gerson no. 421A) and Dou (Geneva, Musée des Beaux-Arts), it was used to illustrate "touch" in pictures of the five senses: an example of an allegory turning into a genre-scene and thence into an entirely different allegory. ${ }^{46}$ But the original sense of the pierre de tête picture was still half-alive in the eighteenth century, for a French engraving after Teniers (impression in the Wellcome Institute) has the legend L'OPERATION INUTILE.

The Wellcome Institute's collection has representatives of each of these three groups: Huys in the first, Quast in the second, and in the third several unpublished pictures, one of which is illustrated in fig. 5. It is a highly finished watercolour, dated 1787, painted by Jacob Cats of Amsterdam after a painting, then in Gouda, by Dominicus van Tol (c. 1635-1676), the nephew and imitator of Gerrit Dou. ${ }^{17} \mathrm{~A}$ barber-apothecary is prising a painful eruption out of the forehead of an elderly woman.

ts "Folly", a kind of moral disorder (mōria, stultitia, Narrheit, dwaasheid etc.), not the physical disorder "madness" (mania, vesania, Wahnsinn, dolkoppigheid etc.). "Madness" was, and is, thought to have a physical cause. Therefore it was reasonable to attempt to cure it by medicine or surgery. Folly, on the other hand, was not recognized as a disease; therefore to treat it as if it were a disease was itself an act of folly. That is the central point of the pierre de tête pictures. It is true that in speech, in belles-lettres, and, in this case, in fine art, the two terms were, and are, used metaphorically for each other; but the concepts remained distinct. Henry Meige and Michel Foucault, and their respective followers, have been misled by the ambiguity of la folie.

46 An English engraving after Teniers has the legend 'Feeling' and some doggerel verses to the same effect. Compare the representations of touch in the 'Five senses' pictures of the Utrecht school, e.g. leeching in Jan van Bijlert's painting in the Landesmuseum, Hanover; Michael Sweerts' Girl with a bandaged finger on loan to the Boymans-van Beuningen museum, Rotterdam; and Gonzales Coques' phlebotomy scene in the National Gallery, London.

${ }^{7}$ On paper, $410 \times 320 \mathrm{~mm}$. Inscribed on verso "J. Cats del naar een schilderij van van Tol ... [name of owner undeciphered] . . . a Gouda. $A^{\circ}$ 1787", and on mount "J. Cats fec. na. D: van Toll". Van Tol's painting has not been located. 


\section{William Schupbach}

Whether it is an inflammation or a pierre de tête is left to us to decide, but the artist, by painting the patient in profile, has withheld the evidence we need to make the diagnosis. The painting is therefore delicately balanced between a pierre de tête scene and a genre-picture. The spectator may appreciate both elements, as well as the ambiguity between them, without enrolling the operator into that "interesting group of quacks, especially numerous in the Low Countries", who are supposed to have practised "den berühmten Steintrick, eine Scheinoperation". For there appears to be not a shred of evidence that those celebrated quacks ever existed.

\section{SUMMARY}

Many Netherlandish pictures of the sixteenth and seventeenth centuries show an operator making an incision in the patient's head in order to remove an object, usually a stone. The usual interpretation of these scenes is that they show quacks who claimed to cure mental diseases by cranial lithotomy, the stone being secretly produced by themselves. In the absence of documentary evidence of such a practice, it is more likely that the pictures are to be interpreted as allegories, moralities, or theatrical scenes, as in two pictures, here reproduced, by Pieter Huys and Pieter Quast. However, the pictures do contain a valuable residue of evidence for surgical history. Bosch's picture in this cycle raises peculiar problems.

\section{APPENDIX}

THE PIERRE DE TÊTE SCENE ATTRIBUTED TO BOSCH

This picture, one of the possessions of the Prado, has several peculiar features which demand comment.

The inscription implies that the picture was painted to a specific scenario in which a certain "Lubbert Das" is treated by a surgeon in the presence of the other characters. The words "My name is Lubbert Das" suggest a new character in a play introducing himself to the audience, or the explanatory caption to a passing carnival-float. The precise purport of the scene will only be known if the scenario is found. The comparative materials adduced by Roggen and Bax shed little light on the picture's narrative content.

The inscription was designed, and perhaps painted, not by Bosch but by a professional scribe. The inscriptions with the best claim to be by Bosch - for instance those on the 'Garden of delights' outer panel and on the Ecce Homo in Frankfurt are crude by comparison.

The background of the painting is independent of the foreground. The grass in the foreground suddenly fades, in both colour and texture, where the background starts. The content of the picture leads one to the same conclusion: what is this heavy domestic furniture doing in the middle of the open countryside?

The picture as we have it is therefore a work of at least three different authors: the background-painter, the foreground-painter, and the epigraphist. The composer of the inscription may have been a fourth contributor if different from the epigraphist. The composer may not have seen the painting, nor the painters have known the exact text, at the time they were executing their different tasks. Hence the possibility of divergences between text and painting. 


\section{A new look at The cure of folly}

There are in fact such divergences. The inscription suits a genre-like scene in which a surgeon cuts stones out of the patient's head, as in the Rijksmuseum version of the picture. In this painting, however, we find features which are alien to a genre-scene, but at home in Bosch's demoniacal and fantastic pictures. The funnel-hat occurs so frequently in Bosch that there is no need to cite examples. Similar hats are also found in medieval illuminated MSS of Apocalypsis and Fulgentius metaforalis, which may have influenced Bosch. The book floating on the woman's head is paralleled in the 'Garden of delights' right wing. A demon standing next to the harp has a book on his head, and so does an inconspicuous figure in the bottom right hand corner; his book is a financial document, to judge from the similar books in the Death of the miser picture in Washington. The same defiance of gravity is shown by the gigantic die floating on the head of the naked female reveller. The flowers coming out of the patient's head have no exact parallel elsewhere, but there are similar scenes. Flowers in a ewer hang over the piper's head in the Haywain centre panel. In the Lisbon St. Antony centre panel, a demon has a flower-pot head with white flowers in it. In the 'Garden of delights' left wing, a cliff with a human face has a big tree growing out of its forehead. The painter has adapted this motif for a keisnijding scene so that the operator is actually digging the flowers out of the patient's head.

Since the strange features of the pierre de tête picture occur in such a variety of contexts in Bosch's demoniacal pictures, they cannot have here the particular meanings which have been assigned to them: for example, that the funnel is a symbol of wisdom, crookery, or pharmacy; that the book is a book of tricks or of medical knowledge; that the flower is a Dutch pun on a word meaning also a stone or a fool. Most of these interpretations are unsubstantiated anyway, and some of them simply impossible. It is more likely that the discrepancies between the inscription and the picture are due to a want of co-ordination between the authors' intentions. For the same reason, there is no need to relate the gallows in the background to the pseudosurgical scene in the foreground.

The picture reproduced by I. M. de Groot and D. de Moulin (op. cit., note 12 above, pp. 29-30) is not the Prado version as stated there, but the very different version in the Rijksmuseum, Amsterdam. 